\title{
EFEKTIVITAS INFUSA DAUN SAWO (Manilkara zapota L.) TERHADAP PERTUMBUHAN Salmonella thypi
}

\author{
Rusdiaman $^{*}$, Sisilia Teresia Dewi \\ ${ }^{1,2}$ Jurusan Farmasi Poltekkes Kemenkes Makassar
}

${ }^{*}$ Koresponden : Rusdiaman, Email : rusdhy71@gmail.com HP : 081342465458

DOI: https://doi.org/10.32382/mf.v15i1.859

\begin{abstract}
ABSTRAK
Telah dilakukan penelitian tentang Uji Efektivitas Infus Daun Sawo (Manilkara zapota L.) Terhadap Pertumbuhan Salmonella thypi yang bertujuan untuk menentukan nilai MIC (Minimum Inhibitory Concentration) dan MKC (Minimum Killing Concentration) dari infus Daun Sawo terhadap Salmonella thypi. Ekstraksi dilakukan dengan menggunakan metode infus untuk menyari zat aktif dan dibuat dengan konsentrasi 5\%, 10\%, 15\%, 20\%, 25\%, 30\%, 35\%, 40\%, 45\% dan $50 \%$ b/v. Penentuan MIC dilakukan dengan metode dilusi cair setelah $1 \times 24$ jam diinkubasi sedangkan penentuan MKC dilakukan setelah inkubasi selama $2 \times 24$ jam. Hasil penelitian menunjukkan bahwa nilai MIC dari infus Daun Sawo terhadap Salmonella thypi adalah konsentrasi $30 \%$ dan nilai MKC dari infus Daun Sawo terhadap Salmonella thypi adalah konsentrasi $50 \%$.
\end{abstract}

Kata kunci : Daun Sawo, Salmonella thypi, Dilusi Cair, MIC dan MKC

\section{PENDAHULUAN}

Penggunaan bahan alam sebagai obat tradisional di Indonesia telah dilakukan oleh nenek moyang kita sejak berabad-abad yang lalu terbukti dengan adanya naskah lama pada daun lontar Husodo (jawa), Usada (Bali), Lontarak pabbura (Sulawesi Selatan), dokumen Serat Primbon Jampi, Serat Racikan Boreh Wulang Dalem dan relief candi Borobudur yang menggambarkan orang sedang meracik obat (jamu) dengan tumbuhan sebagai bahan bakunya. (Sukandar. E Y, 2006).

Obat herbal telah diterima secara luas di hampir seluruh negara di dunia. Menurut WHO, negara-negara di Afrika, Asia dan Amerika Latin menggunakan obat herbal sebagai pelengkap pengobatan primer yang mereka terima. Bahkan di Afrika, sebanyak $80 \%$ dari populaasi menggunakan obat herbal untuk pengobatan primer (WHO, 2003).

Faktor pendorong terjadinya peningkatan penggunaan obat herbal dinegara maju adalah usia harapan hidup yang lebih panjang pada saat prevalensi penyakit kronik meningkat,adanya kegagalan penggunaan obat modern untuk penyakit tertentu diantaranya kanker serta semakin luas akses informasi mengenai obat herbal di seluruh dunia. (Sukandar. E Y, 2006)
Manilkara zapota umumnya dikenal sebagai sawo adalah tanaman berumur panjang dan tersebar asli dari Meksiko selatan, Amerika Tengah dan Karibia dan merupakan spesies tanaman subdominant. Diperkenalkan ke Filipina selama penjajahan Spanyol. Hal ini tumbuh dalam jumlah besar di India, Thailand, Malaysia, Kamboja, Indonesia, Bangladesh dan Meksiko. (Hogan., Cleveland, 2010).

Berdasarkan penelitian sebelumnya, daun dan batang sawo ternyata mengandung flavonoida. Disamping itu daun juga mengandung saponin dan batangnya juga mengandung tanin, zat inilah yang mengambil peranan penting dalam menyembuhkan berbagai penyakit tersebut (diare, radang mulut, batu ginjal). Getah buah dan daun Manilkara zapota berkasiat sebagai obat disamping itu getahnya dapat digunakan untuk campuran gula-gula. Air seduhan daun sawo yang sudah agak tua atau semacam teh demam, diare dan disentri. (Mayarista, 2013).

Sawo mengandung sejumlah vitamin antioksidan seperti vitamin C (24,5\% dari asupan harian per $100 \mathrm{~g}$ buah), dan vitamin A. Vitamin A penting untuk penglihatan. Hal ini juga diperlukan untuk menjaga selaput lendir sehat dan kulit. Konsumsi buah-buahan alami yang kaya akan vitamin A telah dikenal untuk 
menawarkan perlindungan dari paru-paru dan rongga mulut kanker. Begitu juga, konsumsi makanan yang mengandung vitamin $\mathrm{C}$ membantu tubuh mengembangkan resistensi terhadap agen infeksi dan membantu mengikat radikal bebas berbahaya dari tubuh manusia. (USDA National Nutrient database, 2016).

Pada penelitian Junita Mayarista Simanullang 2013, hasil uji aktivitas antibakteri ekstrak kasar daun Sawo (Manilkara zapota), terhadap bakteri Escherichia coli dan Staphylococcus aureus menunjukkan adanya aktivitas penghambatan pertumbuhan, hal tersebut dapat dilihat dari hasil pengukuran zona bening yang terbentuk yaitu berupa wilayah jernih disekeliling kertas cakram yang mengandung ekstrak daun sawo.

Berdasarkan uraian diatas peneliti tertarik untuk melakukan penelitian penentuan nilai MIC dan MKC infus Daun Sawo terhadap pertumbuhan Salmonella thypi dengan menggunakan metode dilusi cair. Berdasarkan latar belakang diatas, maka permasalahan yang akan muncul yaitu berapa besar konsentrasi infus Daun Sawo yang efektif terhadap bakteri Salmonella thypi ? Adapun tujuan dari penelititan ini adalah untuk menentukan MIC (Minimum Inhibitory Concentration) dan MKC (Minimum Killing Concentration) dari infus Daun Sawo terhadap bakteri Salmonella thypi.

\section{METODE}

\section{Jenis Penelitian}

Penelitian ini termasuk penelitian eksperimental laboratorium. Penelitian ini dilakukan untuk mengetahui efektivitas yang ditimbulkan dari infus Daun Sawo (Manilkara zapota L) terhadap Salmonella thypi.

\section{Bahan Uji}

Bahan uji yang digunakan adalah simplisia Daun Sawo (Manilkara zapota L.) yang diperoleh dari Kota Sengkang, Kabupaten Wajo, Sulawesi Selatan. Infus Daun Sawo (Manilkara zapota L.) yang digunakan terdiri dari 10 konsentrasi yaitu $5 \%, 10 \%, 15 \%, 20 \%, 25 \%, 30 \%, 35 \%, 40 \%$, $45 \%$, dan 50\%. Adapun antibiotik pembanding yang digunakan adalah
Kloramfenikol. Media yang digunakan adalah Natrium Broth (NB).

\section{Bakteri Uji}

Bahan uji yang digunakan adalah biakan murni Salmonella thypi yang diremajakan dengan media Nutrien Agar (NA).

\section{Parameter Yang Akan Diukur}

Parameter uji pada penelitian ini adalah penentuan Minimum Inhibitory Concentration (MIC) berupa nilai optical density (OD), sedangkan penentuan Minimum Killing Concentration (MKC) yang diamati yaitu dengan melihat ada atau tidaknya pertumbuhan koloni bakteri pada konsentrasi tertentu pada media.

\section{Tempat dan Waktu Penelitian}

Penelitian ini dilakukan di Laboratorium Mikrobiologi Politeknik Kesehatan Kemenkes Makassar Jurusan Farmasi pada Bulan Mei 2017.

\section{Alat dan Bahan}

Alat-alat yang digunakan adalah autoklaf, batang pengaduk, Erlenmeyer ,Inkubator, Gelas Ukur, kain flannel,Laminary Air Flow, oven, Panci infus, penangas air, pinset, Rak tabung reaksi, tabung reaksi, pinset, spoit, thermometer, sendok tanduk, timbangan analitik. Sedangkan bahan-bahannya adalah Isolat bakteri Salmonella thypi, Daun Sawo (Manilkara zapota L), Nutrient Broth (NB) Mc .Farland 0,5, Aquadest Steril, Ethanol.

\section{Penyiapan Bahan}

a. Pengambilan bahan uji tanaman yang berupa Daun Sawo diambil secara langsung dari Kota Sengkang, Kabupaten Wajo, Sulawesi Selatan.

b. Untuk membuat infus 5\% ditimbang $5 \mathrm{~g}$ Daun Sawo kemudian ditambahkan aquadest $100 \mathrm{ml}$ kemudian dipanaskan pada suhu $90^{\circ} \mathrm{C}$ selama 15 menit, dengan prosedur yang sama untuk membuat infus $10 \%$ ditimbang $10 \mathrm{~g}$ Daun Sawo kemudian ditambahkan aquadest $100 \mathrm{ml}$ kemudian dipanaskan pada suhu $90^{\circ} \mathrm{C}$ selama 15 menit begitu seterusnya untuk membuat infus dengan konsentrasi $15 \%$, $20 \%, 25 \%, 30 \%, 35 \%, 40 \%, 45 \%, 50$ $\%$ sambil sekali-kali diaduk, kemudian 
dilakukan penyaringan untuk mendapatkan larutan infusnya saja apabila infusa yang didapat kurang dari 100 ml,maka dilakukan penambahan aquadest yang panas pada ampas daun sirih dan disaring kembali sampai infus mencapai $100 \%$.

c. Bakteri Uji dalam penelitian ini adalah suspensi bakteri Salmonella thypi yang telah disetarakan tingkat kekeruhannya dengan Mc. Farlands 0,5 dan ditanam di media NB. Biakan murni Salmonella thypi diperoleh dari Laboratorium Mikrobiologi Jurusan Farmasi Politeknik Kesehatan Kemenkes Makassar

d. Pembuatan suspensi Salmonella thypi Bakteri uji yang telah diremajakan selama 24 jam, masing-masing diambil 1 ose kemudian disuspensikan ke dalam larutan $\mathrm{NaCl}$ fisiologis $0,9 \%$ steril, setelah itu dihomogenkan dan diseterakan dengan standar Mc.Farland 0,5 .

e. Penyiapan bahan uji

Bahan uji dibuat dengan mengencerkan Infus Daun Sawo dengan pelarut aquadest. Konsentrasi bahan uji yang digunakan adalah 5\%, 10\%, 15\%, 20\%, $25 \%, 30 \%, 35 \%, 40 \%, 45 \%, 50 \%$ b/v.

f. Pembuatan larutan Kloramfenikol

Ditimbang $250 \mathrm{mg}$ Kloramfenikol dilarutkan dalam $100 \mathrm{ml}$ aquadest dengan konsentrasi 2500 ppm. Dari konsentrasi 2500 ppm, diukur $10 \mathrm{ml}$ kemudian diencerkan dalam $100 \mathrm{ml}$ aquadest dengan kosentrasi $250 \mathrm{ppm}$. Dari konsentrasi 250 ppm diukur $10 \mathrm{ml}$ kemudian diencerkan menjadi $50 \mathrm{ml}$ hingga mencapai konsentrasi 50 ppm.

\section{Cara Kerja}

Penelitian ini menggunakan bahan uji berupa sediaan Salmonella thypi dan Infus Daun Sawo. Konsentrasi Infus Daun Sawo yang digunakan 10 konsentrasi yaitu $5 \%$, $10 \%, 15 \%, 20 \%, 25 \%, 30 \%, 35 \%, 40 \%, 45 \%$ dan $50 \%$ b/v. Tabung 1 diisi $1 \mathrm{ml}$ Infus Daun Sawo dengan konsentrasi bahan uji $5 \%$ b/v dalam media NB ditambah $0,05 \mathrm{ml}$ suspensi bakteri Salmonella thypi. Tabung 2 diisi $1 \mathrm{ml}$ Infus Daun Sawo dengan konsentrasi bahan uji $10 \%$ b/v dalam media NB ditambah 0,05 $\mathrm{ml}$ suspensi bakteri Salmonella thypi. Tabung 3 diisi $1 \mathrm{ml}$ Infus Daun Sawo dengan konsentrasi bahan uji $15 \% \mathrm{~b} / \mathrm{v}$ dalam media NB ditambah $0,05 \mathrm{ml}$ suspensi bakteri Salmonella thypi. Tabung 4 diisi $1 \mathrm{ml}$ Infus Daun Sawo dengan konsentrasi bahan uji $20 \% \mathrm{~b} / \mathrm{v}$ dalam media NB ditambah $0,05 \mathrm{ml}$ suspensi bakteri Salmonella thypi. Tabung 5 diisi $1 \mathrm{ml}$ Infus Daun Sawo dengan konsentrasi bahan uji $25 \% \mathrm{~b} / \mathrm{v}$ dalam media NB ditambah $0,05 \mathrm{ml}$ suspensi bakteri Salmonella thypi. Tabung 6 diisi $1 \mathrm{ml}$ Infus Daun Sawo dengan konsentrasi bahan uji $30 \%$ dalam media NB ditambah $0,05 \mathrm{ml}$ suspensi bakteri Salmonella thypi. Tabung 7 diisi $1 \mathrm{ml}$ Infus Daun Sawo dengan konsentrasi bahan uji $35 \%$ b/v dalam media NB ditambah $0,05 \mathrm{ml}$ suspensi bakteri Salmonella thypi. Tabung 8 diisi $1 \mathrm{ml}$ Infus Daun Sawo dengan konsentrasi bahan uji $40 \% \mathrm{~b} / \mathrm{v}$ dalam media NB ditambah $0,05 \mathrm{ml}$ suspensi bakteri Salmonella thypi. Tabung 9 diisi $1 \mathrm{ml}$ Infus Daun Sawo dengan konsentrasi bahan uji $45 \%$ b/v dalam media NB ditambah $0,05 \mathrm{ml}$ suspensi bakteri Salmonella thypi. Tabung 10 diisi $1 \mathrm{ml}$ Infus Daun Sawo dengan konsentrasi bahan uji 50 $\%$ b/v dalam media NB ditambah $0,05 \mathrm{ml}$ suspensi bakteri Salmonella thypi. Tabung 11 sebagai kontrol obat $(\mathrm{K}+)$ diisi $5 \mathrm{ml}$ media NB ditambahkan $1 \mathrm{ml}$ Kloramfenikol 50 ppm kemudian ditambahkan 0,05 $\mathrm{ml}$ suspensi bakteri. Tabung 12 sebagai kontrol aquadest (K-) diisi $5 \mathrm{ml}$ media NB ditambahkan $1 \mathrm{ml}$ aquadest dan ditambahkan $0,05 \mathrm{ml}$ suspensi bakteri. Tabung 13 sebagai kontrol media diisi $5 \mathrm{ml}$ media NB.

Perlakuan di atas dilakukan pengulangan sebanyak tiga kali. Kesemua tabung diinkubasi pada suhu $37^{\circ} \mathrm{C}$ selama $1 \mathrm{x}$ 24 jam, kemudian diamati. Konsentrasi terendah dari larutan bahan uji yang dapat menghambat pertumbuhan bakteri (ditandai dengan kejernihan secara visual oleh tiga pengamat secara independen) ditentukan sebagai Minimum Inhibitory Consentration (MIC).

Guna mengetahui Minimum Killing Consentration (MKC), larutan tadi diinkubasi lanjut pada suhu $37^{\circ} \mathrm{C}$ selama $2 \times 24$ jam. MKC ditentukan pada konsentrasi terendah dimana pada media tidak terdapat pertumbuhan koloni bakteri.

Dari metode ini dapat ditentukan konsentrasi Minimum Inhibitory Consentration (MIC) yaitu kadar terkecil dari Infus Daun Sawo yang dapat menghambat 
pertumbuhan Salmonella thypi dan juga konsentrasi Minimum Killing Consentration (MKC) yaitu kadar terkecil dari Infus Daun Sirih yang dapat membunuh pertumbuhan Salmonella thypi dari setiap percobaan/replikasi. Sehingga dari rata-rata tersebut dapat diketahui nilai MIC dan MKC.

\section{HASIL}

Penelitian ini bertujuan untuk mengetahui daya antibakteri infus daun sawo pada pertumbuhan Salmonella thypi dengan menggunakan metode dilusi cair guna untuk menentukan Minimum Inhibitory Consentration (MIC) dan Minimum Killing Consentration (MKC). Berikut merupakan tabel hasil pengamatan MIC dan MKC .

\section{PEMBAHASAN}

Telah dilakukan penelitian di Laboratorium Mikrobiologi Farmasi Politeknik Kesehatan Makassar dengan maksud untuk menetukan nilai MIC (Minimum Inhibitory Concentration) dan MKC (Minimum Killing Concentration). MIC adalah konsentrasi minimal dari Infus Daun Sawo yang dapat menghambat pertumbuhan Salmonella thypi. Parameter yang digunakan adalah tingkat kekeruhan dari perlakuan dibandingkan dengan kontrol (perlakuan tanpa inokulasi bakteri) dan dilakukan selama $1 \times 24$ jam ( 1 hari). MKC yaitu konsentrasi minimal Infus Daun Sawo yang dapat membunuh Salmonella thypi dengan parameter yang digunakan adalah tingkat kekeruhan dari perlakuan dibandingkan dengan kontrol (perlakuan tanpa inokulasi bakteri) yang dilakukan terhadap inkubasi lanjutan MIC selama $2 \times$ 24 jam (2 hari).

Hasil pengamatan menunjukkan bahwa Infus Daun Sawo dapat menghambat pertumbuhan Salmonella thypi dengan nilai MIC $30 \%$ b/v dan berpotensi membunuh Salmonella thypi dengan nilai MKC 50\% b/v.

Pada penelitian ini digunakan metode infus untuk menyari zat aktif dari bahan uji Daun Sawo. Metode ini merupakan salah satu metode untuk menyari kandungan aktif dari Daun Sawo dengan teknik pemanasan. Metode infundasi digunakan untuk menyari kandungan aktif dari simplisia yang larut dalam air panas. Penyarian dengan cara ini menghasilkan sari yang tidak stabil dan mudah tercemar oleh bakteri dan jamur sehingga sari yang diperoleh dengan cara ini harus segera diproses sebelum 24 jam. (BPOM,2013)

Metode pengujian pada penelitian ini adalah uji MIC (Minimum Inhibitory Concentration) dengan mengambil nilai konsentrasi terendah yang dapat menghambat pertumbuhan bakteri dan uji MKC (Minimum Killing Concentration) dengan mengambil konsentrasi terendah yang dapat membunuh bakteri .

Parameter yang digunakan pada penentuan MIC (Minimum Inhibitory Concentration) adalah tingkat kekeruhan dari perlakuan dibandingkan dengan kontrol (perlakuan tanpa inokulasi bakteri) dan parameter yang digunakan untuk menentukan MKC (Minimum Killing Concentration) adalah tingkat kekeruhan perlakuan dibandingkan dengan kontrol (perlakuan yang tidak dilakukan inokulasi bakteri). (Lay, 2002)

Hasil pengamatan menunjukkan bahwa pada hari pertama (inkubasi selama 1 $\times 24$ jam), tabung dengan konsentrasi 30\% terjadi penghambatan pertumbuhan bakteri sehingga dapat dinyatakan bahwa MIC dari infus Daun Sawo (Manilkara zapota L.) terhadap Salmonella thypi adalah konsentrasi $30 \%$. Penelitian dilanjutkan pada hari ke-2 (inkubasi $2 \times 24$ jam) untuk menentukan MKC dan diperoleh hasil pada konsentrasi $50 \%$ tidak ditumbuhi lagi bakteri. Sedangkan pada kontrol positif yang berisi obat kloramfenikol replikasi ke-3 terjadi pertumbuhan bakteri, hal ini menujukkan bahwa kemungkinan dosis yang digunakan terlalu kecil atau bakteri yang digunakan resisten terhadap antibiotik kloramfenikol.

Penelitian ini dipilih nilai MIC pada konsentrasi $30 \%$ dan nilai MKC pada konsentrasi $50 \%$. Hal ini menunjukkan bahwa bahan uji potensial sebagai antibakteri. Potensi ini disebabkan oleh adanya zat aktif dalam bahan uji seperti flavonoid, saponin dan tanin yang telah dibuktikan pada penelitian sebelumnya (Mayarista, 2013).

\section{KESIMPULAN}

Berdasarkan hasil penelitian dan dari hasil pembahasan, maka dapat disimpulkan bahwa nilai MIC (Minimum Inhibitory Concentration) dari infus Daun Sawo terhadap pertumbuhan Salmonella 
thypi adalah 30\% dan nilai MKC (Minimum Killing Concentration) dari infus Daun Sawo terhadap pertumbuhan Salmonella thypi adalah $50 \%$.

\section{SARAN}

Berdasarkan hasil penelitian dan hasil pembahasan maka disarankan untuk dilakukan penelitian lebih lanjut terhadap mekanisme kerja Infusa Daun Sawo terhadap Salmonella thypi .

\section{DAFTAR PUSTAKA}

Butar-Butar, N. 2015. Pengaruh ekstrak buah Sawo Manila (Achras zapota L) $1 \%$ dalam bentuk obat kumur terhadap akumulasi plak. [online] Repository.usu.ac.id.

Tersedia:http://repository.usu.ac.id/ xmlui/handle/ 123456789/49401 [18 Jan. 2017].

Cdc.gov. (2017). General Information Typhoid Fever. CDC. [online] Tersedia:https://www.cdc.gov/typh oid-fever/sources.html [18 Jan. 2017].

Crfg.org. (2017). SAPODILLA Fruit Facts. [online] Tersedia: https://www.crfg.org/pubs/ff/sapodi 1la.html [18 Jan. 2017].

Dalimartha, S. (2006). Atlas tumbuhan obat Indonesia. 1st ed. Jakarta: Puspa Swara.

Ditjen POM. 2000. Parameter Standar Umum Ekstrak Tumbuhan Obat. Cetakan Pertama. Jakarta: Departeman Kesehatan RI. Halaman. 10-12.

Direktorat Obat Asli Indonesia, 2013, Pedoman Teknologi Formulasi Sediaan Berbasis Ekstrak, Volume Kedua, Badan Pengawas Obat dan Makanan, Jakarta.

Farmasiana.2017.chloramphenicol:Dosis obat Kegunaan Efek samping. [online]Tersedia:http://www.farmas iana.com/chloramphenicol/kloramf enikol/ [26 Jan. 2017].

Healthbeckon. 2014. 15 Amazing Benefits \& Uses Of Sapodilla / Chikoo. [online] Healthbeckon.com.Tersedia:http:// www.healthbeckon.com/sapodillachikoo-benefits/ [26 Jan. 2017].

Lay, Bibiana W. 2002. Analisis Mikroba Di Laboraturium. Jakarta : PT. Raja Grafindo Persada

McGinley Mark, Hogan C.Michael and Cleveland. C. 2010. World Wildlife Fund. eds.. Petenes mangroves. Encyclopedia of Earth. National Council for Science and the Environment. Washington DC

NCCLS.2003. Methods for Dillution Antimicrobial Susceptibility Test for Bacteria that Grow AerobicallySixth Edition: Approved Standard M7-A6. NCCLS, Wayne, PA, USA.

Pakadang,S.R., Ahmad, T., 2011. Buku Ajar Mikrobiologi Farmasi. Edisi pertama. Makassar: Kementerian Kesehatan RI.

Radji,M.2009. Buku Ajar Mikrobiologi: Panduan Mahasiswa Farmasi Dan Kedokteran. Edisi pertama. Jakarta: Penerbit Buku Kedokteran EGC.

Simanullang, JM.2013. Uji Antibakteri Daun Sawo (Manilkara zapota L.) Terhadap Bakteri Eschericia Coli, dan Staphylococcus Aureus. [online]Repository.usu.ac.id. http://repository.usu.ac.id/handle/12 3456789/42682 [23 Jan. 2017].

Sukandar,EY,2016, Tren dan Paradigma Dunia Farmasi, Industri-KlinikTeknologi Kesehatan. [online] Orasi ilmiah Dies Natalis ITB, Tersedia:http://itb.ac.id/focus/focus _file/orasi-ilmiah-dies-45.pdf.[23 Januari 2017].

Tabel 1. Hasil Pengujian Minimum Inhibitory Concentration (MIC) infus Daun Sawo ( Manilkara zapota L.) terhadap pertumbuhan Salmonella thypi 


\begin{tabular}{ccccccccccccccccccc}
\hline \\
\hline
\end{tabular}

Keterangan :

(+) : : Ada pertumbuhan Salmonella thypi

$(-)$

: Tidak ada pertumbuhan Salmonella thypi

$\mathrm{K}(-) \quad$ : Tabung reaksi yang berisi air dan suspensi Salmonella thypi

$\mathrm{K}(+) \quad$ : Tabung reaksi yang berisi media, larutan obat Kloramfenikol suspensi

Salmonella thypi

M : Tabung reaksi yang hanya yang berisi media

M + Daun Sawo $\quad$ : Tabung reaksi yang berisi media dan infusa Daun Sawo

Tabel 2. Hasil Pengujian Minimum Killing Concentration (MKC) infus Daun Sawo ( Manilkara zapota L.) terhadap pertumbuhan Salmonella thypi

\begin{tabular}{|c|c|c|c|c|c|c|c|c|c|c|c|c|c|c|}
\hline $\begin{array}{l}\text { Konsentrasi } \\
\text { Tabung }\end{array}$ & $5 \%$ & $10 \%$ & $15 \%$ & $20 \%$ & $25 \%$ & $30 \%$ & $35 \%$ & $40 \%$ & $45 \%$ & $50 \%$ & $\begin{array}{l}\mathrm{K} \\
+\end{array}$ & $\begin{array}{c}\mathrm{K} \\
-\end{array}$ & $\mathrm{M}$ & 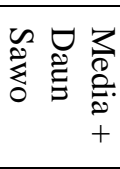 \\
\hline 1 & + & + & + & + & + & + & + & - & - & - & - & + & - & - \\
\hline 2 & + & + & + & + & + & + & + & + & - & - & - & + & - & - \\
\hline 3 & + & + & + & + & + & - & - & + & + & - & + & + & - & - \\
\hline $\mathrm{pH}$ & & & & & & 6 & 6 & 6 & 6 & 6 & 5 & 7 & 6 & 7 \\
\hline
\end{tabular}

Keterangan :

(+) : : Ada pertumbuhan Salmonella thypi

(-) : : Tidak ada pertumbuhan Salmonella thypi

$\mathrm{K}(-) \quad$ : Tabung reaksi yang berisi air dan suspensi Salmonella thypi

$\mathrm{K}(+) \quad$ : Tabung reaksi yang berisi media, larutan obat Kloramfenikol suspensi

Salmonella thypi

M : Tabung reaksi yang hanya yang berisi media

M + Daun Sawo : Tabung reaksi yang berisi media dan infusa Daun Sawo 